\title{
Antibiotics sensitivity of Candida clinical and food-borne isolates*
}

\author{
Marta Maroszyńska ${ }^{1,2}$, Alina Kunicka-Styczyńska', Katarzyna Rajkowska ${ }^{1}$ and Iwona \\ Maroszyńska³
}

1Department of Biotechnology and Food Science, Institute of Fermentation Technology and Microbiology, Lodz University of Technology, Łódź, Poland; 2Biotechnology Laboratory, Regional Park of Science and Technology Ltd., Łódź Poland; ' ${ }^{2}$ Department of Intensive Care and Congenital Newborn and Infants, Polish Mother's Memorial Hospital Research Institute, Łódź Poland

Candida is a yeast species recognized as the most frequent etiological agent of systemic and invasive thrush in humans. Invasions can affect all tissues, organs and systems of human in various stages of development. In the last 10 years Candida infections have increased 15 times. The purpose of our study was to determine the sensitivity of four antibiotics belonging to three different groups of antifungal agents against clinical and food-borne Candida strains. Our studies showed that of all tested strains, $7 \%$ was resistant to nystatin, $32 \%$ to fluconazole, $23 \%$ to voriconazole, and no strains grew in the presence of caspofungin. Despite the differences in biochemical profiles of clinical and food-borne isolates of Candida, a group of strains showing resistance to antibiotics include both types of isolates. At the same time circulating of antibiotic-resistant strains outside the hospital environment and the yeast infection via food is possible.

Key words: Candida, fluconazole, voriconazole, caspofungin, nystatin, clinical and food strains

Received: 31 October, 2013; revised: 04 December, 2013; accepted: 17 December, 2013; available on-line: 30 December, 2013

\section{INTRODUCTION}

Candida yeasts are natural inhabitants of the alimentary, genital and upper respiratory tracts of mammals (Szczepaniak et al., 2004; Tunka et al., 2006). Approximately $40-60 \%$ of people are carriers of Candida, however, it does not mean that the clinical Candidiasis occurs (Ibanez-Nolla et al., 2004). Candida is recognized as the most frequent etiological agent of systemic and invasive thrush in humans among which the most common is Candida albicans (80-90\%). Invasions can affect all tissues, organs and systems of human in various stages of development. Probability of infections is growing with specific conditions of the organism and in particular during predisposing situations, like: diabetes, pregnancy, use of antibiotics, cortisones, contraceptives, estrogens, immunosuppresors, methronidozol, genetic factors, etc. (Tunka et al., 2006; Torba et al., 2012; Silva et al., 2012). In the past ten years, Candida infections have increased 15 times (Kenedy \& Wolz, 2007; Torba et al., 2012).

The discovery and development of antibiotics for the treatment of microorganisms infections was one of the most significant medical achievements of the twentieth century. Nowadays, at least a few hundred of antibiotics are known, but this does not mean a sense of security. Having the vast number of drugs, which at the time of entry into treatment were completely new agents, we used them fairly lightly. In last few years, among factors contributing to fungal colonization, use of antibiotics with broad spectrum of antibacterial activity is the most significant. According to statistics from the monitoring of antibiotic consumption of European Surveillance of Antibiotic Consumption, Poland is in the top ten among European countries in terms of quantitative antibiotic consumption per capita (Dzierżanowska, 2001; Kostecka, 2011). Unfortunately, many of existing antimicrobial agents are under threat from the widespread emergence of microorganisms resistance (Kuźma et al, 2007; Deptuła \& Gospodarek, 2010). This huge number of resistant species is mainly caused by abuse of all antibiotics in the treatment and also in the treatment of viral infections (Dzierżanowska, 2001, Lewis \& Ausubel, 2006; Straus \& Hancock, 2006; Kaufman, 2011). Antibiotic-resistant strains of Candida circulate in human environment and colonize diverse environment, they get also into the food. Highly-processed food is not generally contaminated with yeasts of the Candida genus. However, the food products, fermented products and products with a low degree of processing are not free from these yeasts. The presence of the yeast in the food is well documented (Tornai-Lehoczki et al., 2003; Tyrer et al., 2004; Bajpai et al., 2011), but only few works concern the study of antibiotic resistance of food-borne isolates.

Within the presented study the sensitivity of both clinical and food-borne Candida strains against antibiotics belonging to three different groups was determined. The following antibiotics were used: nystatin (polyenes), fluconazole and voriconazole (triazoles I and II generation, respectively) and caspofungin (echinocandins).

\section{MATERIALS AND METHOD}

Yeast species. 44 strains of Candida were tested (Table 1). Clinical strains of Candida albicans $(\mathrm{cl} / \mathrm{MP} / 1 \mathrm{~K}, \mathrm{cl} /$ $\mathrm{MP} / 2 \mathrm{~K}, \mathrm{cl} / \mathrm{MP} / 3 \mathrm{~K}, \mathrm{cl} / \mathrm{MP} / 4 \mathrm{~K}, \mathrm{cl} / \mathrm{MP} / 6 \mathrm{~K}, \mathrm{cl} / \mathrm{MP} / 7 \mathrm{~K}$, $\mathrm{cl} / \mathrm{MP} / 8 \mathrm{~K}, \quad \mathrm{cl} / \mathrm{MP} / 1 \mathrm{M}, \quad \mathrm{cl} / \mathrm{MP} / 2 \mathrm{M}, \quad \mathrm{cl} / \mathrm{MP} / 3 \mathrm{M}, \mathrm{cl} /$ $\mathrm{MP} / 4 \mathrm{M}, \mathrm{cl} / \mathrm{MP} / 01, \mathrm{cl} / \mathrm{MP} / 03, \mathrm{cl} / \mathrm{MP} / 04, \mathrm{cl} / \mathrm{MP} / 05$, $\mathrm{cl} / \mathrm{MP} / 06, \mathrm{cl} / \mathrm{MP} / 07, \mathrm{cl} / \mathrm{MP} / 08, \mathrm{cl} / \mathrm{MP} / 09, \mathrm{cl} / \mathrm{MP} / 12$, $\mathrm{cl} / \mathrm{OZ} / \mathrm{g} 1, \mathrm{cl} / \mathrm{OZ} / \mathrm{g} 2, \mathrm{cl} / \mathrm{OZ} / \mathrm{g} 3, \mathrm{cl} / \mathrm{OZ} / \mathrm{k} 1)$, Candida glabrata (cl/KL/01) and Candida lusitaniae (cl/KL/02) were obtained from Department of Laboratory Diagnostics of Polish Mother's Memorial Hospital and Health

e-mail: mmaroszynska@gmail.com

*Presented at the 3-rd Workshop on Microbiology "MIKROBIOT 2013" in Łódź, Poland. 
Table 1. Number and origin of isolates tested.

\begin{tabular}{|c|c|c|}
\hline Strains & No. of isolates & Origin \\
\hline \multicolumn{3}{|l|}{ Clinical isolates } \\
\hline \multirow{6}{*}{ C. albicans } & 15 & faeces \\
\hline & 3 & throat \\
\hline & 3 & vagina \\
\hline & 1 & blood \\
\hline & 1 & skin \\
\hline & 1 & stomach \\
\hline C. glabrata & 1 & urogenital tract \\
\hline C. Iusitaniae & 1 & faeces \\
\hline \multicolumn{3}{|c|}{ Food-borne isolates } \\
\hline \multirow{2}{*}{ C. Iusitaniae } & 2 & fruit yoghurt \\
\hline & 2 & feed \\
\hline \multirow{2}{*}{ C. krusei } & 3 & pickled cucumber \\
\hline & 1 & bakery \\
\hline C. boidinii & 3 & pickled cucumber \\
\hline \multirow{2}{*}{ C. famata } & 1 & fruit yoghurt \\
\hline & 1 & salad \\
\hline C. collicullosa & 1 & fruit yoghurt \\
\hline C. parapsilosis & 1 & fruit yoghurt \\
\hline C. tropicalis & 1 & pickled cucumber \\
\hline C. pelliculosa & 1 & feed \\
\hline C. rugosa & 1 & sauerkraut \\
\hline
\end{tabular}

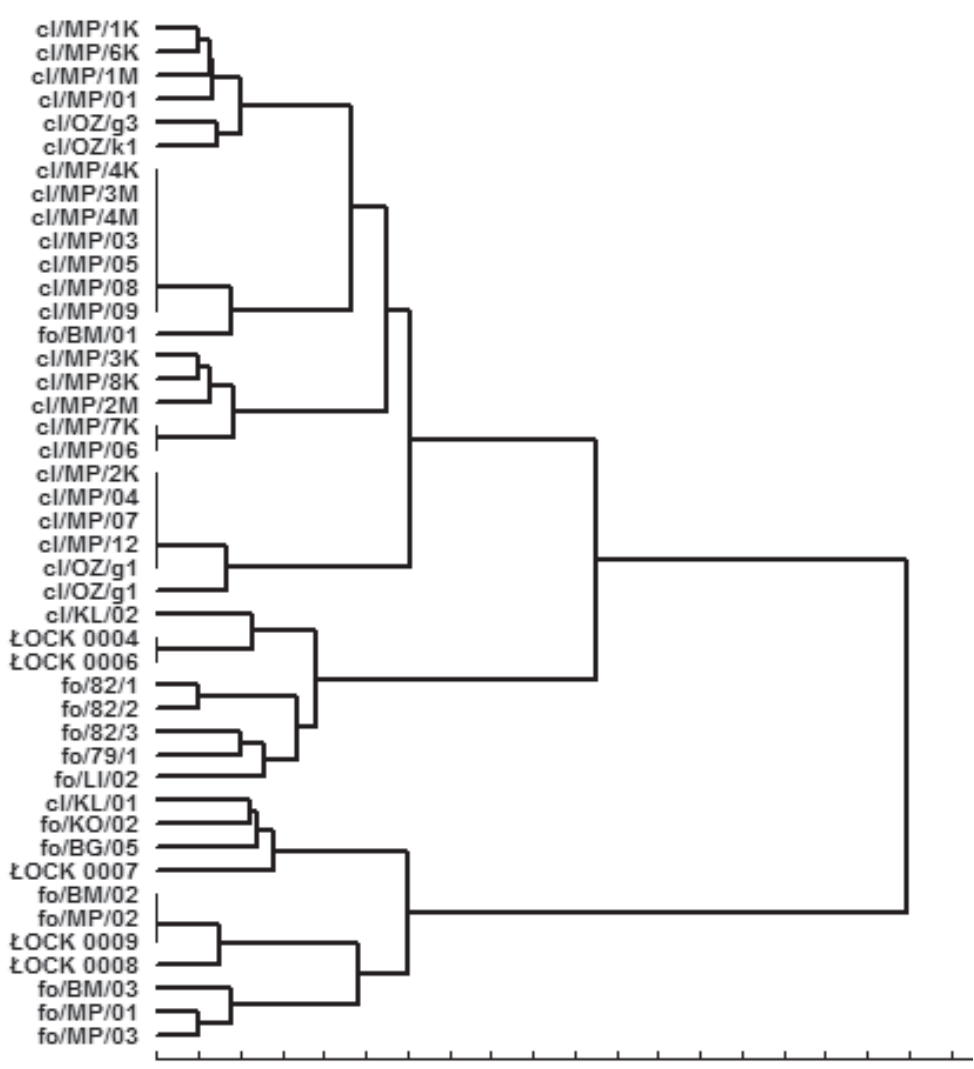

Figure 1. Dendrogram of similarity of Candida strains biochemical properties estimated by API 20C AUX tests (bioMerieux).
Care Team of Lodz Polesie, while food-borne strains of Candida lusitaniae (fo/82/1, fo/79/1, LOCK 0004, LOCK 0006), Candida famata (fo/82/2, fo/LI/2), Candida parapsilosis (fo/82/3), Candida colliculosa (fo/KO/02), Candida tropicalis (fo/BM/01), Candida krusei (fo/BM/02, fo/MP/02, LOCK 0008, LOCK 0009), Candida boidinii (fo/BM/03, fo/MP/01, fo/MP/03), Candida rugosa (fo/ BG/05) and Candida pelliculosa (LOCK 0007) were obtained from Institute of Fermentation Technology and Microbiology of Lodz University of Technology and various commercial companies.

Yeast maintenance and activation. Yeast strains were maintained on agar YPG medium ( $1 \%$ bacto yeast extract, $2 \%$ bacto peptone, $2 \%$ glucose, $2 \%$ bacto agar) slants. The strain activation was carried out by double passaging of 24 hours yeast culture in YPG liquid medium, in temperature $37^{\circ} \mathrm{C}$.

Biochemical properties. API 20C AUX tests (bioMerieux, France) were used for biochemical characteristics of the yeast. All procedures were conducted according to manufacturer recommendation. The biochemical profiles of Candida isolates were estimated according to the yeast abilities to assimilate 19 substrates: glucose, glycerol, 2-keto-D-gluconate, L-arabinose, D-xylose, adonitol, xylitol, galactose, inositol, sorbitol, $\alpha$-methylD-glucoside, N-acetyl-D-glucosamine, cellobiose, lactose, maltose, sucrose, trehalose, melezitoze, raffinose.

Antibiotics. The following antibiotics were used: caspofungin acetate (1-[(4R,5S)-5-[(2-aminoethyl) amino]-N2-[(10R,12S)-10,12-dimethyl-1-oxotetradecyl]4-hydroxy-L-ornithine]-5-(threo-3-hydroxy-L-ornithine) pneumocandin B0 Diacetat at the concentration of $5 \mu \mathrm{g} / \mathrm{mL}$ (Laboratories Merck Sharp \& Dohme-Chibret, France); voriconazole ((2R,3S)-2-(2,4-difluorphenyl)3-(5-fluor-4-pyrimidinyl)-1-(1H-1,2,4-triazol-1-yl)butan-2-ol) at the concentration of $1 \mu \mathrm{g} /$ disc (Becton, Dickinson \& Co., USA); fluconazole (2-(2,4-difluorophentyl)-1,3-bis(1H1,2,4-triazol-1-yl)propan-2-ol) at the concentration of $25 \mu \mathrm{g} /$ disc (Becton, Dickinson \& Co., USA); nystatin $(1 S, 3 R, 4 R, 7 R, 9 R, 11 R, 15 S, 16 R$, 17R,18S,19E,21E,25E,27E,29E,31 E,33R, 35S,36R,37S)-33-[(3-amino3,6-dideoxy- $\beta$ - $D$-mannopyranosyl) oxy]-1,3,4,7,9,11,17,37-octahydroxy15,16,18-trimethyl-13-oxo-14,39dioxabicyclo-nonatriaconta-19,21, 25,27,29,31-hexaene-36-carboxylic acid) at the concentration of 50 $\mu \mathrm{g} / \mathrm{mL}$ (PPH Galfarm Sp z o.o., Polska).

Antifungal activity assessment. Agar disc diffusion method was used for screening of antifungal activity of each antibiotic. Yeast inoculum $\left(10^{3} \mathrm{cfu} / \mathrm{mL}\right)$ in $0.85 \%$ $\mathrm{NaCl}$ solution was spread on the surface of YPG agar plate. Sterile filter paper discs $(6 \mathrm{~mm}$ in diameter) with $50 \mu \mathrm{g}$ of nystatin, $25 \mu \mathrm{g}$ of fluconazole, $1 \mu \mathrm{g}$ of voriconazol and with $10 \mu$ l of caspofungin acetate in the concentration of $5 \mu \mathrm{g} /$ $\mathrm{ml}$ were placed on the inoculated plates. The positive control consisted of water instead of antibiotics, while uninoculated plates con- 
Table 2. Interpretive chart of diameter zone of growth inhibition for nystatin, fluconazole, voriconazole and caspofungin according to manufacturers of antibiotics.

\begin{tabular}{|c|c|c|c|}
\hline \multirow{2}{*}{ Antifungal agent } & \multicolumn{3}{|c|}{ Zone Diameter Interpretive Standards [mm] } \\
\hline & Resistant (R) & Intermediate (I) & Susceptible (S) \\
\hline Caspofungin acetate & $\leq 12$ & $13-15$ & $\geq 16$ \\
\hline Voriconazole & $\leq 13$ & $14-16$ & $\geq 17$ \\
\hline Fluconazole & $\leq 14$ & $15-18$ & $\geq 19$ \\
\hline Nystatin & no zone & $10-14$ & $\geq 15$ \\
\hline
\end{tabular}

only two isolates were identified as C. glabrata and C. Iusitaniae. Pickled cucumbers $(39 \%)$ and fruit yoghurt $(28 \%)$ were the main source of food-borne Candida. C. Iusitaniae and $C$. krusei represented the largest number of isolates. Neither $C$. albicans nor C. glabrata typically isolated from human were not found in food. The only genus isolated from these two sources simultaneously was C. Iusitaniae.

Hierarchical cluster analysis aptaining antibiotics served as a negative control. All plates were incubated for $48 \mathrm{~h}$ at $37^{\circ} \mathrm{C}$. Size of inhibition zone diameters surrounding filter paper disc was measured and compared to the Zone Diameter Interpretive Standards (Table 2).

Statistical analysis. Hierarchical cluster analysis was used to estimate the similarity of Candida strains according to their biochemical profiles and susceptibility to antibiotics. Outcomes of biochemical properties were displayed as binary data, 0 or 1 when the feature was absent or present in the yeast profile, respectively. Whereas the results of yeasts antibiotic-sensitivity were presented as the average value of growth inhibition zones diameter for each examined antibiotic. The algorithm for hierarchical clustering was calculated by Ward's method (Statistica 6.0, Stat Soft Inc.) and cluster hierarchy was presented using a tree structure (dendrogram) with horizontal agglomeration distance.

Statistic development zones of inhibition. Diameter zone of growth inhibition is presented as average value of four measurements and standard deviations were calculated (Microsoft Excel 2010).

\section{RESULTS AND DISCUSSION}

Most of 26 clinical strains used in researches were isolated from the faeces $(61 \%)$, vagina $(11 \%)$ and throat $(11 \%)$. C. albicans was predominated in this group and plied for similarity assessment of Candida isolates according to their biochemical profiles showed differentiation of the strains in the two clusters (Fig. 1). The first cluster includes 24 clinical strains of $C$. albicans and foodborne C. tropicalis (fo/BM/01) isolated from pickled cucumbers. The second cluster, except 17 strains originatglabrata (cl/KL/01) and C. Iusitaniae (cl/KL/02). At the same time, distinct biochemical heterogeneity was stated among the isolates of $C$. albicans. It is probably conditioned by an adaptation of the yeast to host organism.

Candida isolates were evaluated for sensitivity to four antibiotics. All isolates were found sensitive to caspofungin that was expressed by growth inhibition zones ranged from 18 to $49 \mathrm{~mm}$. Caspofungin is a valuable fairly new antifungal agent with a novel mechanism of action belonging to the class echinocandins (McCormack \& Perry, 2005; Wieczorek et al., 2008). In the early 2000's, echinocandins were licensed for the treatment and prevention of fungal infections (Finkelman, 2010; Al-Badriyeh et al., 2012; Lobo et al., 2013). Spectrum of caspofungin activity is relatively broad including Candida and Aspergillus species, and mycelial forms of endemic fungi (Wieczorek et al., 2008; Wiederhold \& Herrera, 2012). The high effectiveness of this antibiotic is attributed to an inhibition of the glucan synthase complex in yeast cells, that is why it is an attractive taring from food matrices, includes two clinical strains $C$.

Table 3. Antibiotics sensitivity of Candida strains classified as diameter of growth inhibition zones:

$\mathrm{R}$ - resistant, I - intermediate, $\mathrm{S}$ - susceptible, measured by the disc diffusion method.

\begin{tabular}{|c|c|c|c|c|c|c|c|c|c|}
\hline \multirow[b]{2}{*}{ Yeast $^{*}$} & & \multicolumn{7}{|c|}{ Average diameter zone of antibiotics [mm] } & \\
\hline & & Caspofungin & & Voriconazole & & Fluconazole & & Nystatin & \\
\hline C. albicans & $\mathrm{cl} / \mathrm{MP} / 1 \mathrm{M}$ & $46.75 \pm 5.38$ & $S$ & 0 & $\mathrm{R}$ & 0 & $\mathrm{R}$ & 20.00 & $\mathbf{S}$ \\
\hline C. albicans & $\mathrm{cl} / \mathrm{MP} / 01$ & $18.50 \pm 0.58$ & S & 0 & $\mathrm{R}$ & 0 & $\mathrm{R}$ & 0 & $\mathrm{R}$ \\
\hline C. albicans & cl/MP/03 & $20.50 \pm 0.58$ & S & $20.50 \pm 1.73$ & S & $15.75 \pm 2.50$ & 1 & 20.00 & $\mathbf{s}$ \\
\hline C. albicans & $\mathrm{cl} / \mathrm{MP} / 04$ & $19.50 \pm 1.29$ & S & 0 & $\mathrm{R}$ & 0 & $\mathrm{R}$ & 19.00 & $\mathbf{S}$ \\
\hline C. albicans & $\mathrm{cl} / \mathrm{MP} / 05$ & $23.50 \pm 0.58$ & $S$ & 0 & $\mathrm{R}$ & 0 & $\mathrm{R}$ & $25.50 \pm 0.58$ & $S$ \\
\hline C. albicans & $\mathrm{cl} / \mathrm{MP} / 08$ & $23.00 \pm 1.41$ & S & 0 & $R$ & 0 & $\mathrm{R}$ & $19.25 \pm 0.96$ & $\mathrm{~S}$ \\
\hline C. albicans & $\mathrm{cl} / \mathrm{MP} / 09$ & $23.50 \pm 0.58$ & $S$ & $13.25 \pm 1.26$ & I & $10.50 \pm 0.58$ & $\mathrm{R}$ & $20.50 \pm 0.58$ & $\mathrm{~S}$ \\
\hline C. glabrata & $\mathrm{cl} / \mathrm{KL} / 01$ & 25.00 & S & $11.50 \pm 0.58$ & $\mathrm{R}$ & 9.00 & $\mathrm{R}$ & 25.00 & $\mathrm{~S}$ \\
\hline C. boidinii & fo/MP/01 & $27.50 \pm 1.29$ & $S$ & $30.25 \pm 1.26$ & $S$ & $16.00 \pm 1.63$ & I & $30.50 \pm 0.58$ & $\mathrm{~S}$ \\
\hline C. boidinii & fo/MP/03 & $26.00 \pm 0.82$ & $S$ & $15.25 \pm 1.26$ & I & 0 & $\mathrm{R}$ & $31.50 \pm 1.29$ & $\mathrm{~S}$ \\
\hline C. rugosa & fo/BG/05 & $23.25 \pm 0.50$ & $S$ & $14.50 \pm 0.58$ & I & $7.50 \pm 0.58$ & $\mathrm{R}$ & $29.25 \pm 0.96$ & $\mathrm{~S}$ \\
\hline C. tropicalis & fo/BM/01 & $23.50 \pm 0.58$ & $\mathrm{~S}$ & 0 & $\mathrm{R}$ & 0 & $\mathrm{R}$ & 0 & $\mathrm{R}$ \\
\hline C. krusei & fo/BM/02 & $28.75 \pm 1.50$ & $\mathrm{~S}$ & $23.75 \pm 2.06$ & $S$ & $14.50 \pm 1.29$ & I & $34.50 \pm 5.20$ & S \\
\hline C. boidinii & fo/BM/03 & $29.50 \pm 0.58$ & $\mathrm{~S}$ & $32.75 \pm 2.22$ & $S$ & $16.75 \pm 2.06$ & I & $30.50 \pm 0.58$ & $\mathrm{~S}$ \\
\hline C. pelliculosa & ŁOCK 0007 & $30.75 \pm 0.96$ & $\mathrm{~S}$ & $35.00 \pm 0.82$ & $S$ & $33.50 \pm 1.29$ & $\mathrm{~S}$ & 0 & $\mathrm{R}$ \\
\hline
\end{tabular}

"All strains not included in the Table 3 were sensitive to all antibiotics tested. 

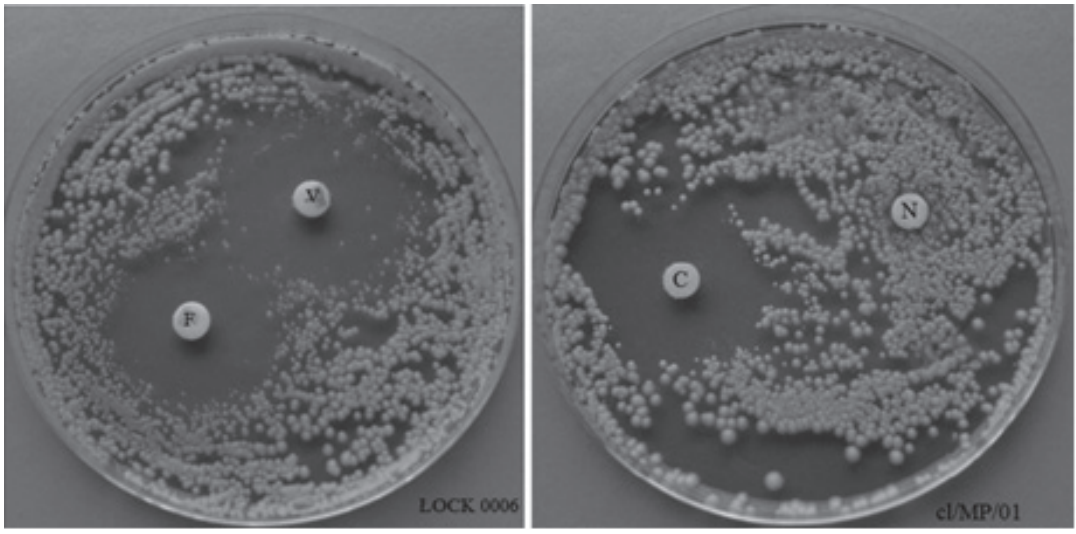

Figure 2. Examples of antibiotics susceptibility of food borne isolate Candida lusitaniae ŁOCK 0006 (left) and clinical isolate Candida albicans cl/MP/01 (right) estimated by agar disc diffusion method.

Symbols: F — fluconazole, V - voriconazole, C - caspofungin, $\mathrm{N}$ - nystatin.

get due to the lack of homologous enzymes in human cells (Dominguez-Gil et al., 2007; Marchettia et al., 2007; Wieczorek et al., 2008). Caspofungin is mainly used in hospital treatment, so it is possible that the yeast had not yet developed resistance systems to this antibiotic and are still sensitive.

Due to different sensitivity to nystatin, fluconazole and voriconazole 15 strains were grouped together (Table 3).

Triazoles, which did not totally inhibit growth of the clinical isolates and only against five food-borne strains showed the lowest effectiveness. Azoles were introduced to the therapy in the 1980s. Mechanism of these drugs action is impaired synthesis of ergosterol in the fungal plasma membrane, with the participation of cytochrome P450. Voriconazole also inhibits the synthesis of chitin (Pfaller et al., 2003, Cuenca-Estrella et al., 2005; Szymankiewicz \& Dancewicz, 2008). Similar mechanism of action can explain the similarity of activity against tested Candida strains. Triazoles, particularly fluconazole, are firstline drugs in the treatment of fungal infections. Spectrum of activity of fluconazole does not include infections caused by Candida glabrata and Candida krusei (Pfaller et al., 2003; Cuenca-Estrella et al., 2005; Spelberg et al., 2006; Szymankiewicz \& Dancewicz, 2008). However, in our study, two food-borne strains of C. krusei showed a susceptibility to fluconazole, while the third one was intermediate. There were no resistant strains of C. krusei to fluconazole. Only one clinical isolate of C. glabrata was tested on the activity of antibiotics and it was not sensitive to fluconazole. Voriconazole is a triazole of the second generation. It is used for invasive Candida infections caused by strains resistant to fluconazole. This antibiotic shows a strong activity against Candida including C. krusei and C. glabrata (Pfaller et al., 2003; Cuenca-Estrella et al.,

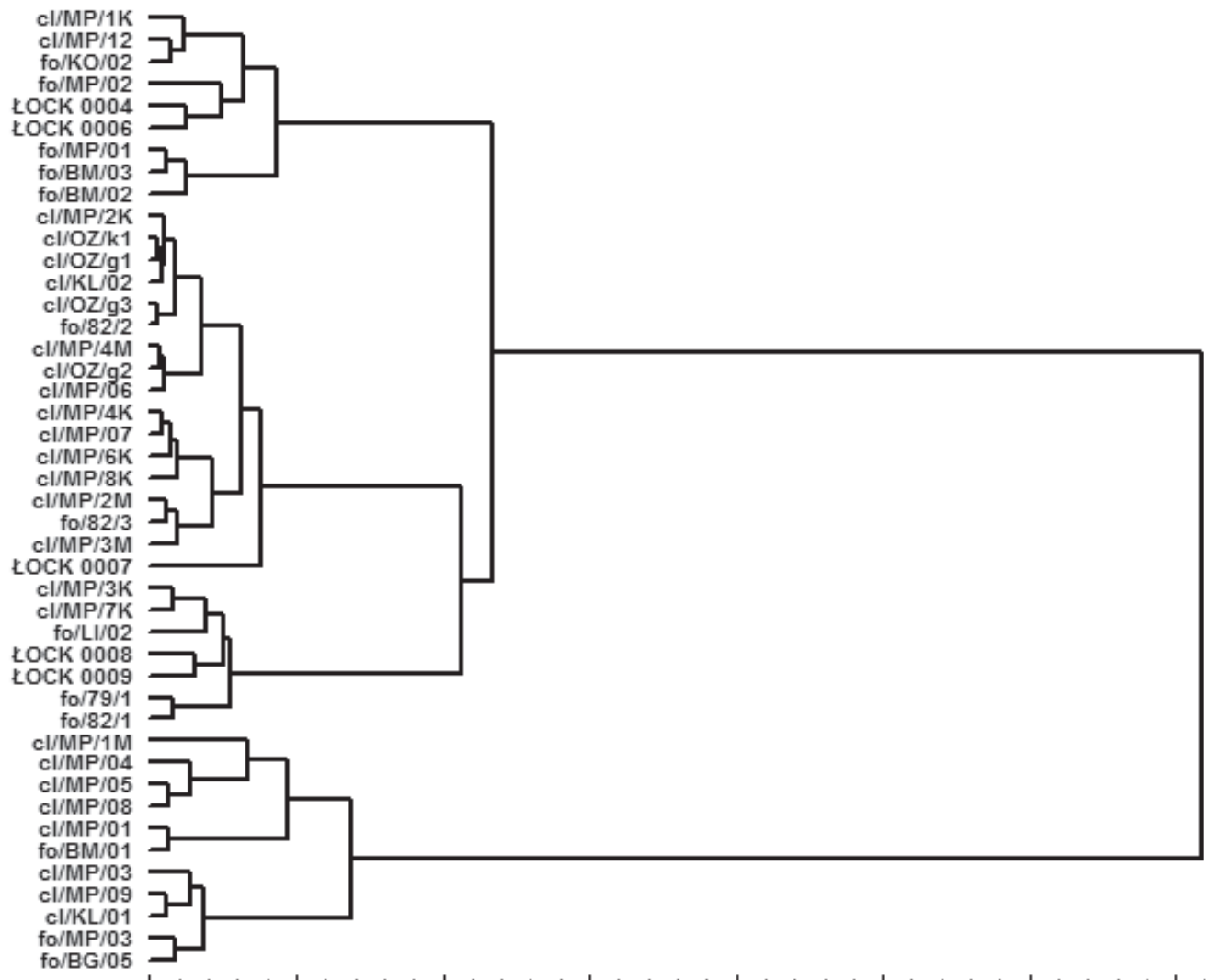

Figure 3. Dendrogram of similarity of Candida yeasts sensitivity to different antibiotics.

The sensitivity was estimated by the agar disc diffusion method. 
2005; Panackal et al., 2006; Spelberg et al., 2006; Szymankiewicz \& Dancewicz, 2008). In our research, voriconazole effectively inhibited growth of $C$. krusei, however, $C$. glabrata was not sensitive neither to fluconazole nor to voriconazole.

Three isolates were resistant to nystatin: one $C$. albicans clinical strain isolated from faeces and two foodborne strains $C$. tropicalis and $C$. pelliculosa isolated from pickled cucumber and animal feed respectively. Nystatin inhibited growth of $93 \%$ of all the tested strains.

Figure 2 shows representative examples of plates illustrating action of antibiotics on Candida isolates.

According to $\mathrm{Ng}$ et al., 2003 it has been proved to be the most effective agents in the treatment of various fungal infections. In the study of Hossain et al., 2000 was shown that nystatin was effective against some fungal pathogens unresponsive to amphotericin B and azoles. Pharmacological activity of nystatin comes from the interaction with ergosterol found in the plasma membrane of fungal cells with subsequent functional disorder of the membrane, resulting in yeast death (Barăo de Aguiar et al., 2010). Unfortunately, the toxicities caused by polyene antibiotics limit their use $(\mathrm{Ng}$ et al., 2003; Hossain et al., 2000; Chandrasekar, 2011; Semis et al., 2012). Nystatin is not absorbed through the skin or from the gastrointestinal track, and so topical and oral administration of nystatin is not associated with significant toxicities (Hossain et al., 2000; Ng et al., 2003; Chandrasekar, 2011; Semis et al., 2012). That is why it was used as the first-choice drug for the treatment of oral candidiasis (Barâo de Aguiar et al., 2010). In Poland, this antibiotic was widely used during antibioticotheraphy in bacterial infection as a prophylaxis of gastrointestinal candidiasis. Reduced nystatin consumption in the recent years, especially in the prophylactic treatment of fungal infection, could be the reason of sensitivity recovering fungi of recovered its resistance to this antibiotic. The only one resistant strain for voriconazole, fluconazole and nystatin was C. albicans $(\mathrm{cl} / \mathrm{MP} / 01)$ isolated from the faeces.

Similarity of Candida isolates according to their sensitivity to different antibiotics is shown in Fig. 3. Eleven of the 15 isolates showed a resistance or at least intermediate sensitivity to one antibiotic tested form cluster significantly different from the other strains. C. albicans are the majority $(64 \%)$ in this cluster. As in the case of biochemical profiles, food-borne $C$. tropicalis strains (fo/ $\mathrm{BM} / 01$ ) showed high homology with the clinical strains.

\section{CONCLUSIONS}

Among 44 Candida strains tested, neither C. albicans nor $C$. glabrata typically isolated from human, were not found in food. However, according to biochemical profiles C. albicans isolates were distinct from the foodborne ones, a substantial heterogeneity within this group was also noted. Simultaneously, the incidents of biochemical profiles conformity of some clinical and foodborne isolates may be a result of Candida transmission via food. The presented research shows that a group of strains expressing intermediate sensitivity or resistance to the tested antibiotics include both types of isolates. At the same time, the similarity of food-borne C. tropicalis to the clinical strains of $C$. albicans does not exclude the possibility of circulating of antibiotic-resistant strains outside the hospital environment and the yeast infection entered into the body with food. Local monitoring the resistance of environmental Candida strains will be help- ful in making strategic decisions on the use of specific drugs in therapy.

\section{REFERENCES}

Al-Badriyeh D, Liew D, Stewart K, Kong DCM (2012) Pharmacoeconomic analysis of voriconazole vs. caspofungin in the empirical antifungal therapy of febrile neutropenia in Australia. Blackwell Verlag GmbH 55: 244-256.

Barăo de Aguiar MMG, Pereira de Albuquerque R, Marinho DS, Braga DRS, Dornelas CB, Oliveira A, Pereira de Sousa1 V, Torres SR, Alviano DS, Alviano CS, Cabral LM, Holandino C (2010) Oral sustained release nystatin tablets for the treatment of oral candidiasis: formulation development and validation of UV spectrophotometric analytical methodology for content determination. Drug Dev Ind Pharm 36: 594-600.

Bajpai VK, Kang SC, Park E, Jeon WT, Baek KH (2011) Diverse role of microbially bioconverted product of cabbage (Brassica oleracea) by Pseudomonas syringe pv. T1 on inhibiting Candida species. Food Chem Toxicol 49: 403-407.

Chandrasekar P (2011) Management of invasive fungal infections: a role for polyenes. I Antimicrob Chemother 66: 457-65.

Cuenca-Estrella M, Rodriquez D, Almirante B, Morgan J, Planes AM, Almela M, Mensa J, Sanchez F, Ayats J, Gimenez M, Salvado M, Warnock DW, Pahissa A, Rodriquez-Tudella JL (2005) In vitro susceptibilities of bloodstream isolates of Candida species to six antifungal agents: results from a population-based active surveillance programme, Barcelona, Spain, 2002-2003. J Antimicrob Chemother 55: 194-199.

Deptuła A, Gospodarek E (2010) Reduced expression of virulence factors in multidrug-resistant Pseudomonas aeruginosa strains. Arch Microbiol 192: 79-84.

Dominguez-Gil A, Martin I, Garcia Vargas M (2007) Economic evaluation of voriconazole versus caspofungin for the treatment of invasive aspergillosis in Spain. Clin Drug Investig 27: 197-205.

Dzierżanowska D (2001) Antybiotykoterapia praktyczna. A-Medica Press, Bielsko Biała, Polska (in Polish).

Finkelman MA (2010) Pneumocystis jiroveci infection: cell wall (1-3)-3-Dglucan biology and diagnostic utility. Crit Rev Microbiol 36: 271-281.

Hossain MA, Maesaki S, Razzaque MS, Tomono K, Taguchi T, Kohno S (2000) Attenuation of nephrotoxicity by a novel lipid nanosphere (NS-718) incorporating nystatin. I Antimicrob Chemother 46: 263-268.

Ibanez-Nolla J, Nolla-Salas M, Leon M (2004) Early diagnosis of candidiasis in non-neutropenic critically ill patients. J Infect 48: 181-192.

Kaufman G (2011) Antibiotics: mode of action and mechanisms of resistance. Nursing Standard 25: 49-55.

Kenedy M, Wolz P (2007) Ecology of Candida albicans: Inhibition of Candida adhesion, colonization and dissemination from the gastrointestinal tract by bacterial antagonism. Infect Immun 49: 654-663.

Kostecka M. (2011) Kandydoza przewodu pokarmowego u osób leczonych antybiotykami - profilaktyczne stosowanie suplementów diety. Mikol Lek 18: 11-14 (in Polish).

Kuźma L, Różalski M, Walencka E, Różalska B, Wysokińska H (2007) Antimicrobial activity of diterpenoids from hairy roots of Salvia sclarea L.: Salvipisone as a potential anti-biofilm agent active against antibiotic resistant Stapbylococci. Phytomed 14: 31-35.

Lewis K, Ausubel FM (2006) Prospects for plant-dericered antibacterials. Nat Biotechnol 24: 1504-1507.

Lobo ML, Esteves F, Sousa B, Cardoso F, Cushion MT, Antunes F, Matos O (2013) Therapeutic potential of caspofungin combined with trimethoprim-sulfamethoxazole for Pneumocystis pneumonia: a pilot study in mice. PLOS ONE 8: e70619.

Marchettia O, Cordonnierb C, Calandraa T (2007) Empirical antifungal therapy in neutropaenic cancer patients with persistent fever. EJC 5: $32-42$.

McCormack PL, Perry CM (2005) Caspofungin: a review of its use in the treatment of fungal infections. Drugs 65: 2049-2068.

$\mathrm{Ng}$ AW, Wasan KM, Lopez-Berestein G (2003) Development of liposomal polyene antibiotics: a historical perspective. I Pharm Pharm Sci 6: $67-83$.

Panackal AA, Gribskov JL, Staab JF, Kirby KA, Rinaldi M, Marr KA (2006) Clinical significance of azole antifungal drug cross-resistance in Candida glabrata. I Clin Microbiol 44: 1740-1743.

Pfaller MA, Diekema DJ, Messer SA, Boyken L, Hollis RJ (2003) Activities of fluconazole and voriconazole against 1586 recent clinical isolates of Candida species determined by broth microdilution, disk diffusion, and Etest methods: report from the ARTEMIS global antifungal susceptibility program. Clin Microbiol 41: 1440-1446.

Semis R, Nili SS, Munitz A, Zaslavsky Z, Polacheck I, Segal E (2012) Pharmacokinetics, tissue distribution and immunomodulatory effect of intralipid formulation of nystatin in mice. I Antimicrob Chemother 67: 1716-1721.

Silva S, Negri M, Henriques M, Oliveira R, Williams DW, Azeredo A (2012) Candida glabrata, Candida parapsilosis and Candida tropicalis: biol- 
ogy, epidemiology, pathogenicity and antifungal resistance. Microbiol Rev 36: 288-305.

Spellberg BJ, Filler SG, Edwards JE (2006) Current treatment strategy for disseminated candidiasis. Clin Infec. Dis 42: 244-251.

Straus SK, Hancock REW (2006) Mode of action of the new antibiotic for Gram-positive pathogens daptomycin: comparison with cationic antimicrobial peptides and lipopeptides. Acta Biochim Biophys 1758: 1215-1223.

Szczepaniak W, Zawirska A, Adamski Z (200). Rola grzybów drożdżopodobnych rodzaju Candida w etiopatogenezie wybranych schorzeń przewodu pokarmowego. Nowiny Lek 73: 475-478 (in Polish).

Szymankiewicz M, Dancewicz M (2008) Aktywność in vitro worikonazolu i kaspofunginy wobec szczepów Candida spp. oceniana metoda Etestu. Mikol Lek 15: 13-15 (in Polish).

Torba DH, Lika M, Sinani F (2012) Fungi frequence of Candida genus at the pulmonary patents, their identification and characterization. Albanian I Agric Sci 11: 2218-2020.

Tornai-Lehoczki J, Péter G, Dlauchy D (2003) CHROMagar Candida medium as a practical tool for the differentiation and presumptive identification of yeast species isolated from salads. Int I Food Microbiol 86: 189-200.

Tunca R, Tolga GV, Haziroúlu G, Ataseven L, Zen H, Toplu N (2006) Pathological and immunohistochemical investigation of naturally occurring systemic Candida albicans infection in dogs. Turk $J$ Vet Anim Sci 30: 545-551.

Tyrer H, Ainsworth P, Ibanoglu S, Bozkurt H (2004) Modelling the growth of Pseudomonas fuorescens and Candida sake in ready-to-eat meals. J Food Eng 65: 137-143.

Wieczorek P, Sacha P, Żórawski M, Jakoniuk P, Tryniszewska E (2008) Aktywność in vitro kaspofunginy wobec szczepów z rodzaju Candida. Mikol Lek 15: 135-139 (in Polish).

Wiederhold NP, Herrera LA (2012) Caspofungin for the treatment of immunocompromised and severely Ill children and neonates with invasive fungal infections. Clin Med Insights: Pediatrics 6: 19-31. 